\title{
"Organizational conflicts in hospitals and their impact on employee turnover: A case study of Jordan"
}

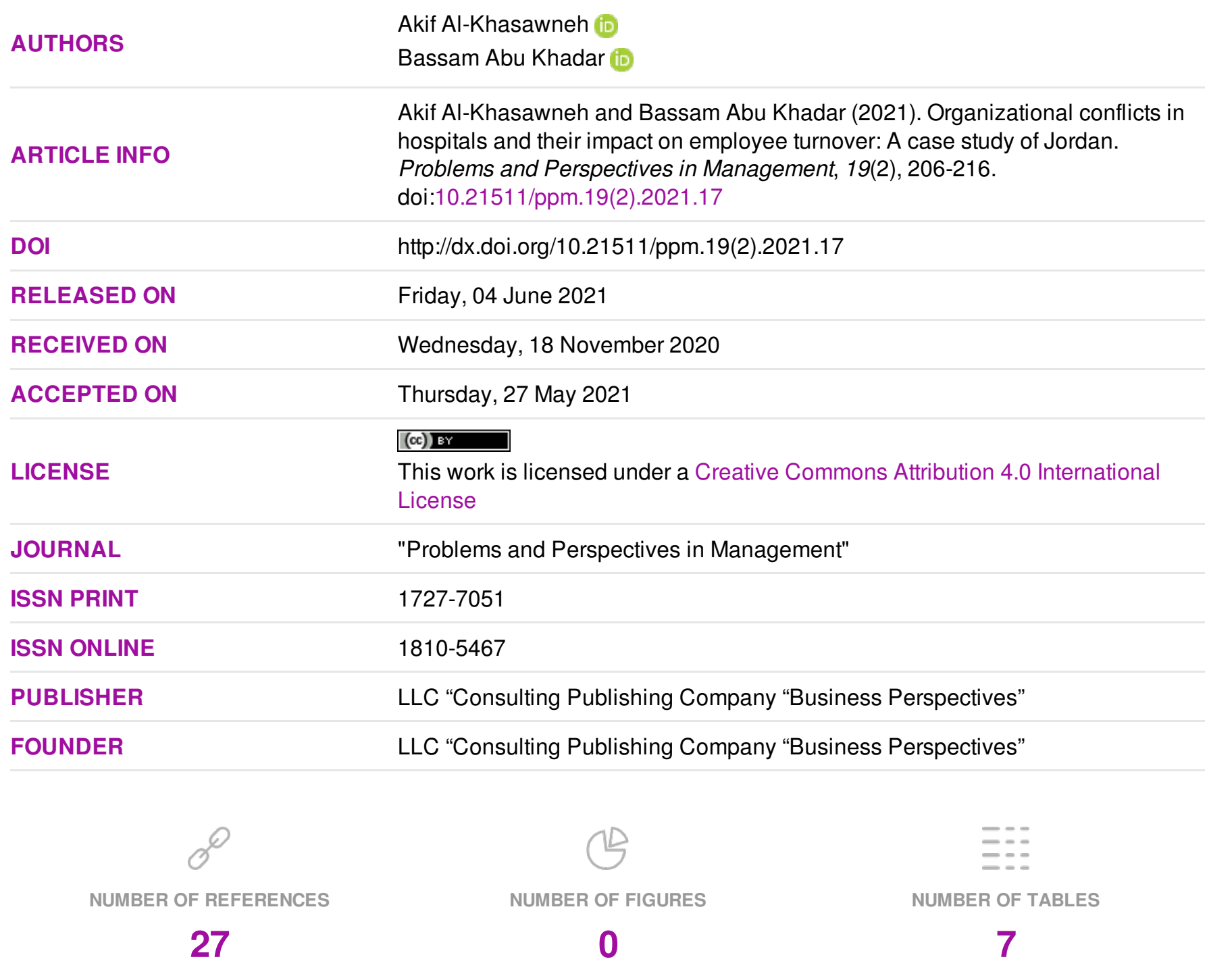

(C) The author(s) 2021. This publication is an open access article. 


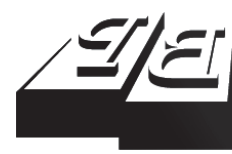

\section{BUSINESS PERSPECTIVES}

()

LLC "CPC "Business Perspectives" Hryhorii Skovoroda lane, 10, Sumy, 40022, Ukraine www.businessperspectives.org
Received on: $18^{\text {th }}$ of November, 2020 Accepted on: 27th of May, 2021 Published on: $4^{\text {th }}$ of June, 2021

() Akif Al-Khasawneh, Bassam Abu Khadar, 2021

Akif Al-Khasawneh, Associate Professor, Department of Financial \& Administrative Sciences, AL-Balqa' Applied University, Irbid, Jordan. (Corresponding author)

Bassam Abu Khadar, Assistant Professor, Department of Financial \& Administrative Sciences, AL-Balqa' Applied University, Irbid, Jordan.
This is an Open Access article, distributed under the terms of the Creative Commons Attribution 4.0 International license, which permits unrestricted re-use, distribution, and reproduction in any medium, provided the original work is properly cited.

Conflict of interest statement: Author(s) reported no conflict of interest

\section{ORGANIZATIONAL CONFLICTS IN HOSPITALS AND THEIR IMPACT ON EMPLOYEE TURNOVER: A CASE STUDY OF JORDAN}

\begin{abstract}
The research aims to investigate the most common types of organizational conflicts among employees in private hospitals and discover the impact of organizational conflicts on employee turnover. The research outlined the relationship between the variables to present the idea of organizational conflicts and employee turnover. The hypotheses were tested using a survey data of 340 questionnaires distributed randomly to employees working in four private hospitals in Jordan. Random selection of private hospitals was made among eight hospitals in the northern governorates of Jordan (Irbid, Jerash, Mafraq, and Ajlun), which are considered the largest districts in the country. The collected data were analyzed using the SPSS program, and initial statistical techniques were applied. The results showed that the highest level of impact of organizational conflicts on the internal turnover of employees was related to the conflict between employees and direct supervisors. However, the highest level of the impact of organizational conflicts on the external turnover of employees was related to the conflict between employees and top management. The low-level job conflicts of employees were those with owners and middle management. Thus, to create stability, prevent work pressure, and retain employees, managers of private hospitals necessarily need to provide an appropriate work environment, develop high level of well-being, and decrease the workload.
\end{abstract}

\section{Keywords \\ workforce planning, employee behavior, human resource management, organizational support, organizational climate, job satisfaction, job stress, Jordan}

JEL Classification D23, D74, J63

\section{INTRODUCTION}

Conflicts among employees of the same organization are considered a phenomenon based on the nature of the daily life of human beings as long as they live together and are governed by the communication relations and the dynamic interaction as well (Omisore \& Abiodun, 2014). For instance, Longe (2015) clarified that personal, mental, functional, and cultural differences among the employees create a way to enable each individual to express thoughts following own needs and desires. Therefore, an organizational conflict will remain and increase especially in large and complicated organizations such as healthcare sector (Shin, 20089). This type of conflicts belongs to what has been called a state of co-existence by one side and the other during the lifetime of organizations that nurture a competitive environment, always seek to expand their activities, aims, and achieve competitive advantages. Presence of an organizational conflict does not mean hiring dictatorial managers, as this will compromise the codes of ethics. However, the main objective of discussing organizational conflicts is to let the managers know the inevitability of job conflicts in the environments of different business organizations. For example, organizational conflicts need a high level of emotionally intelligent managers. 
This will equip them with the ability to manage businesses based on scientific methods that fulfill the aims of the organization and its long-term strategies.

Besides, advocates of the behavioral theory were the first to contribute to managing organizational conflicts and find out scientific and logical solutions. As the result, these solutions gave the employees ways for creativity in the field of performance.

\section{LITERATURE REVIEW}

The review of literature on organizational conflicts in management sciences shows that cases of organizational conflict in business environments have passed through three basic stages (Longenecker \& Pringle, 1984):

First: Traditional thought. This stage dominated from the $19^{\text {th }}$ century until the first half of the $20^{\text {th }}$ century. It adopted the most common types of conflict and how they must be eliminated by all appropriate means.

Second: Behaviorism. This stage started in the fifties of the last century, and it adopted the idea that a conflict is necessary for the organization and cannot be avoided. It purported that management should only recognize the conflict, and determine the acceptable level to serve its objectives.

Third: Interactive thinking. Under this stage, the philosophy adopted believes that a conflict is something normal to happen in the organization. Besides, it stated that a conflict has positive sides, and management does not have to eliminate it. Instead, it has to manage it by some intelligent methods to ensure achieving the balance among employees.

Jawad (2000) discussed that a conflict is a definition used in the field of business administration and other knowledge fields as well. However, using this definition by the behavioral sciences (e.g., business administration) can be manifested in the following:

- Conflicts arise in the organization due to interactions among the elements of work environment, shortage, and scarce resources of the operating activities and other adopted business policies in which a manager will not be able to make the right decision due to the presence of different perspectives.
- The main reason for conflicts is the effective cases faced by management due to some factors and other struggles that are taking place among employees of different levels.

- Conflicts occur among employees of the same organization due to struggles and the level of understanding of cases that happen every day.

- Conflicts occur due to different human behaviors made by employees of the same organization.

Greenberg and Baron (2003) defined an organizational conflict as a confrontation that happens among employees when they feel that an obstacle will threaten their performance. Alfreihat et al. (2009) defined conflict as a case that occurs between two parties or more in the same organization where they work. However, Omyan (2005) defined conflict as a competitive case that occurs between two parties with different aims and profits. Buchanan and Huczynski (2004) defined conflict as behavior that makes negative side effects between two employees.

To achieve the aim of this study, an organizational conflict is defined as a case of tension and struggles that occur in the same work environment, with different job levels, with top or middle management, inner conflicts, and conflicts between employees and customers. Hellriegel et al. (2001) divided an organization conflict into different levels and directions:

First: Conflict at the individual level. This type of conflicts happens among individuals such as managers, consultants, employees, and supervisors due to personal differences. Kondalkar (2007) discussed that this type of conflicts is the most common for business environments.

Second: Conflict at the group level. This type of conflicts occurs between the internal units or in 
the organization itself. For instance, it includes conflicts that may happen between the production and the marketing departments.

Third: Conflict at the organization level. This type of conflicts occurs between the organization and other organizations in the external environment. Such organizations are similar in terms of the activities they undertake. Such competing organizations are driven by the goal of achieving a competitive advantage.

Fourth: Conflict at the employee level. This type of conflicts is psychological and takes place for various reasons including economic, social and family, job and work stress (Keith, 1998). Moorhead and Griffin (1995) mentioned the idea of contradictory objectives as a type of a conflict. There are many types of these contradictory objectives. First: a contradiction in selecting two types of positive objectives. In this case, the employee would prefer to choose them both. Second: a contradiction in selecting undesirable objectives. In this case, the employee must adopt one of these alternatives. Third: a contradiction in selecting positive objectives but with unexpected results. Such types of conflicts happen when the employee attends to accomplish a desired aim but at the same time, results are insufficient.

Concerning employee turnover, there have been more than enough definitions on the matter. However, it is mainly defined as a process in which the employee resigns or moves from one job to another internally or externally (Saeed et al., 2004; Wang et al., 2017). To achieve the goals of the study, the employee turnover was defined as behavior or a process in which the employees seek to resign and leave their present positions to work in another satisfactory one internally or externally. Accordingly, job turnover might be classified into two types. The first one is external employee turnover, when an employee decides to leave his/ her position for another organization (i.e., he/ she resigns). The other type is internal employee turnover, when an employee decides to leave his/ her current position in the same organization for another position. Employee turnover is one of the most weaknesses facing organizations due to individual needs or desires. Hence, management must pay attention to prevent employee turnover espe- cially with the highest qualified employees (AlKhasawneh, 2013).

The subject of this research has taken a wide range of interest, especially in the American, European, and Japanese business organizations. The research is interested in the most outstanding reasons that drive employees to turnover. One of the most reasons that have been highlighted is that conflicts that happen among the employees and top management or conflicts that happen among the employees (Medina, 2012; Omisore \& Abiodun, 2014). Hence, the study focused on organizational conflict and its impact on employee turnover in private hospitals. Hotep et al. (2010) conducted a study to identify the impact of the organizational conflict on the performance of employees in Nigeria. The study showed that the main reason for the intra-firm conflict was scarcity of resources. It was found that the organizational conflict had positive and negative effects, but when properly managed, more positive than negative effects could be achieved. According to Garcia (2013), no negative impact of organizational conflicts on the performance of employees was found. Still, the results indicated that a conflict leads to an increase in the level of competitiveness, productivity, creativity, and innovation. Igbokwe (2014) studied whether an organizational conflict is useful or harmful to the organization. The study concluded that the organizational conflict is necessary because it supports the development and contributes to stimulating innovation. The study recommended that conflicts should be effectively managed since the beginning of the conflict. Omisore and Abiodun (2014) conducted a study on the causes of conflicts in organizations and their impact on employees. The study results showed that the conflict in the organization is natural and must be due to the interactions among the employees in the same organization. Besides, a conflict among employees has negative and positive effects on performance and production, especially if it is well managed by top management and receives early attention before the conflict becomes serious. Longe (2015) conducted a study to identify the impact of a conflict on the business environment in Nigerian organizations in terms of job performance through a random sample of 250 employees. The results showed that there is a statistically significant relationship among conflict management methods 
such as collective negotiations, containment of conflict, long stay of employees in the work environment, and conflicts among employees. The results also showed that conflict situations are natural among employees due to differences in purpose and personal characteristics. Although there are positive and negative results, management responds wisely to activate the positive aspects and reduce the negative ones. A study conducted by Al-Shourah (2015) on the impact of a conflict on the effectiveness of regulations in Jordan found that a conflict among employees in the work environment is normal. It may also occur in any organization and does not constitute a high degree of risk to the organization. The results showed that employees do not prefer conflicts among them because it leads to psychological tension and affect the level of job performance negatively. The study of Eunice et al. (2015) attempted to identify the impact of a personal conflict among job seekers in hotels in Kenya. The study was then conducted on a group of (194) employees. It was found that conflict among the employees is important because it creates competition to achieve better performance among them. It was found that there are no negative effects of employee conflicts on job performance. Said et al. (2016) conducted a study, which aimed to identify the relationship between organizational conflicts and the communication, structure, and personal characteristics of Malaysian companies. The results showed a strong relationship between communication, functional structure, and characteristics of employees. It was found that the communication process plays a powerful role in containing conflicts among employees. However, Malkawi and Omari (2020) aimed to specify the impact of organizational justice on organizational conflict management at Jordanian Marseilles Company. The study found a significant statistical effect of organizational justice on organizational conflict management as a whole and all its indicators (inter-personal conflicts, intra-group conflicts, and organizational conflicts) at $a \leq$ 0.05 . Company management is recommended to expand organizational justice in all dimensions, reinforce the use of organizational justice in managing organizational conflict, and raise awareness of management and employees in the company about how to manage organizational conflict by adopting organizational justice.
Therefore, many studies focused their interest on the role played by the organizational conflict and its impact in all business environments, except for the healthcare sector. Moreover, the interest in the organizational impact on the independent variables was highlighted. Therefore, the current study is highly relevant because it considers a complementary topic and emphasizes its interest in private hospitals that provide a very important service for the patients. It also focuses attention on internal and external employee turnover.

\section{AIM}

This study aims to determine the most prominent types of organizational conflict among employees of private hospitals in Jordan. It also aims to identify the influence of the most common types of organizational conflicts on employee turnover in private hospitals and analyze the most common types of organizational conflicts and their effects on the turnover, based on the variables of sex, years of job experience, and job title.

\section{HYPOTHESES}

This study is based on the following hypotheses:

H01: There is a high impact of organizational conflict on the internal turnover of employees in hospitals, including conflicts between employees and top management, conflicts between employees and middle management, conflicts between employees and direct supervisors, conflicts between employees and other employees of the same job level from different departments, conflicts between employees and other employees in the same organizational units, conflicts between employees and owners, conflicts between employees and customers, and inner conflicts of employees.

H02: There is a high impact of organizational conflicts on the external turnover of employees in hospitals, including conflicts between employees and top management, conflicts between employees and middle management, conflicts between employees and direct su- 
pervisors, conflicts between employees and other employees of the same job level from different departments, conflicts between employees and other employees in the same organizational units, conflicts between employees and owners, conflicts between employees and customers, and inner conflicts of employees.

H03: There are statistically significant differences in the impact of organizational conflicts of employees on employee turnover according to the following personal characteristics: sex, years of job experience, and job title.

\section{METHODOLOGY}

\subsection{Problem}

The problem of the study stems from the burdens that face employees of private hospitals. Such burdens affect and create different conflicts among employees and cause increasing external and internal turnovers. Therefore, different questions are arising out of this problem:

- What are the most common types of organizational conflicts that take place in private hospitals (conflicts between employees and top management, conflicts between employees and middle management, conflicts between employees and direct supervisors, conflicts between employees and other employees of the job level from different departments, conflicts between employees and other employees in the same organizational units, conflicts between employees and owners, conflicts between employees and customers, and inner conflicts of employees)?

- What is the impact of organizational conflict between employees on the internal and external turnover (conflicts between employees and top management, conflicts between employees and middle management, conflicts between employees and direct supervisors, conflicts between employees and other employees of the same level from different departments, conflicts between employees and other employees in the same organizational units, con- flicts between employees and owners, conflicts between employees and customers, and inner conflicts of employees)?

- Is there any statistically significant connection between organizational conflicts and turnover by employees based on the variables of sex, years of job experience, and job title?

\subsection{Significance of the study}

The study is considered significant because it investigates the most common types of organizational conflicts and their impact on employee turnover in hospitals as an important healthcare sector. The study also highlights organizational conflicts that will be used positively by managers and decision-makers. This is realized through benefitting from the results in developing the relations among employees and minimizing the level of conflicts to attain stability and staff retention.

\subsection{Sample}

The study uses the descriptive-analytical approach, which focused only on employees of private hospitals in Jordan. The sample included employees working in administrative and customer service positions. There are eight hospitals and they are operating in four governorates in northern Jordan (Irbid, Jerash, Mafraq, and Ajlun). The study is applied to four private hospitals, which are chosen randomly.

Due to the difficulty of determining a number of employees in private hospitals, 340 questionnaires were distributed randomly among the staff. 302 questionnaires were received back, and 13 questionnaires were excluded because they were not valid for analysis.

Therefore, the number of subjects approved to form the sample of this study is 289 employees, achieving a $85 \%$ response rate.

The questionnaire is based on different studies (AlShourah, 2015; Malkawi, 2017; Said et al., 2016; Malkawi, 2018; Longe, 2015; Al-Khasawneh et al., 2018). The questionnaire is divided into three parts. Part 1 involves personal information about employees. Part 2 measures the types of organizational con- 
flicts in private hospitals. Part 3 measures the impact of organizational conflicts on the internal and external organizational turnover of employees.

\subsection{Variables measurement}

Degree measurement is used in this study by designing a survey that consists of many questions. There are five possible answers as per Likert Scale: (5) very high degree, (4) high degree, (3) medium degree, (2) low degree, and (1) very low degree.

To calculate the mean for each variable, which represents a quantitative measure, the variable is judged statistically to see if it obtains a mean greater than 3.00 , provided that it receives a level of significance from the $t$-test less than 0.05 . Table 1 shows the statistical significance of means.

Table 1. Statistically significant means

\begin{tabular}{l|c}
\hline \multicolumn{1}{c|}{ Significant degree } & Category \\
\hline Low & Less than 2.33 \\
Middle & $2.33-3.66$ \\
\hline High & $3.67-5$ \\
\hline
\end{tabular}

\subsection{Statistical tools}

The Statistical Package for Social Science (SPSS) is used for the descriptive analysis to test the hypotheses of the study and answer the questions as well. Besides, other statistical tools such as frequencies, percentages, standard deviations, means, and $t$-test were used.

\section{RESULTS}

\subsection{Tool reliability}

Tool reliability of the study is measured by Cronbach-Alpha. Table 2 shows that all points were more than 0.60 , which means that the tool used in this study is reliable.

Table 2. Cronbach-Alpha values

\begin{tabular}{l|c}
\hline \multicolumn{1}{c}{ Areas } & Cronbach Alpha \\
\hline Organizational conflicts & 0.85 \\
\hline Internal employee turnover & 0.77 \\
\hline External employee turnover & 0.72 \\
\hdashline Total & 0.88 \\
\hline
\end{tabular}

\subsection{Demographic variables}

Table 3 shows details of personal demographic data for the sample (employees) of the study.

Table 3. Demographic variables

\begin{tabular}{lc:c}
\hline \multicolumn{1}{c}{ Variable } & Mean & Percentage \\
\hline \multicolumn{3}{c}{ Gender } \\
\hline Male & 189 & 60.19 \\
Female & 125 & 39.81 \\
\hline \multicolumn{3}{c}{ Job title } \\
\hline Doctor & 230 & 73.25 \\
\hline Executive & 84 & 26.75 \\
\hline \multicolumn{3}{c}{ Years of job experience } \\
\hline Less than a year & 21 & 6.69 \\
\hline 1-3 years & 49 & 15.61 \\
\hline 4-9 years & 130 & 41.40 \\
More than 10 years & 114 & 36.31 \\
\hline
\end{tabular}

Table 3 shows that males represent $60.19 \%$ of the sample, whereas $39.81 \%$ are females. Doctors represent $73.25 \%$ of the sample, whereas $26.75 \%$ are managerial executives. It also shows $41.40 \%$ of employees who have 4-9 years of experience. There are $36.31 \%$ of employees whose experience is more than 10 years, and $15.61 \%$ whose experience is between 1-3 years. However, there are $6.96 \%$ of employees who have experience of less than one year.

The main question of the study is: what are the most common types of organizational conflicts among employees at private hospitals in Jordan (conflicts between employees and top management, conflicts between employees and middle management, conflicts between employees and direct supervisors, conflicts between employees and other employees of the same level from different departments, conflicts between employees and other employees in the same organizational units, conflicts between employees and owners, conflicts between employees and customers, and inner conflicts of employees)?

Table 4 shows that the highest levels of conflicts are represented by inner conflicts, which is the most common type of conflicts, followed by conflicts between employees and direct supervisors, conflicts between employees and customers, conflicts between employees and top management. However, conflicts with employees from different departments and conflicts among the employees in the same units showed middle results. While 
Table 4. Mean and the most common conflicts ranks

\begin{tabular}{|c|c|c|c|c|}
\hline No. & Items & Mean & Degree & Rank \\
\hline 1 & Conflicts with top management & 3.77 & High & 4 \\
\hline 2 & Conflicts with middle management & 1.50 & Low & 8 \\
\hline 3 & Conflicts between employees and a direct supervisor & 4.46 & High & 2 \\
\hline 4 & Conflicts between employees and other employees in a different department & 3.02 & Middle & 5 \\
\hline 5 & Conflicts between employees and other employees in the same organizational unit & 2.91 & Middle & 6 \\
\hline 6 & Conflicts between employees and owners & 2.11 & Low & 7 \\
\hline 7 & Conflicts between employees and customers & 4.39 & High & 3 \\
\hline 8 & Inner conflicts of employees & 4.48 & High & 1 \\
\hline
\end{tabular}

the lowest level of conflicts is between employees and owners, as well as employees and middle management.

\section{DISCUSSION}

\subsection{Hypothesis 1}

There is a high impact of organizational conflict on the internal turnover of employees in hospitals, including conflicts between employees and top management, conflicts between employees and middle management, conflicts between employees and direct supervisors, conflicts between employees and other employees of the same job level from different departments, conflicts between employees and other employees in the same organizational units, conflict between employees and owners, conflict between employees and customers, and inner conflicts of employees.

Table 5 shows that:

- The mean values for paragraphs $11,12,13$, and 14 were more than 3.00 . The statistical significance was less than 0.05 . This means that organizational conflicts affect employees and employee turnover (conflicts between employees and direct supervisors, conflicts between employees and other employees from different departments, conflicts between employees and other employees in the same organizational units, conflicts between employees and owners).

The mean values for paragraphs $9,10,15$, and 16 were less than 3.00 , which means that it is

Table 5. Means, standard deviations, and T-values for internal turnover

\begin{tabular}{|c|c|c|c|c|c|}
\hline No. & Item & Mean values & $\begin{array}{l}\text { Standard } \\
\text { deviations }\end{array}$ & $T$-values & $\begin{array}{l}\text { Statistical } \\
\text { significance }\end{array}$ \\
\hline 9 & $\begin{array}{l}\text { Conflicts with top management motivate me the } \\
\text { most to seek transfer to other departments in the } \\
\text { organization }\end{array}$ & 2.49 & 1.81 & -3.29 & 0.00 \\
\hline 10 & $\begin{array}{l}\text { Conflicts with middle management motivate me the } \\
\text { most to seek transfer to other departments in the } \\
\text { organization }\end{array}$ & 2.53 & 1.83 & -2.97 & 0.00 \\
\hline 11 & $\begin{array}{l}\text { Conflicts with the direct supervisor motivate me the } \\
\text { most to seek transfer to other departments in the } \\
\text { organization }\end{array}$ & 4.62 & 0.96 & 19.45 & 0.00 \\
\hline 12 & $\begin{array}{l}\text { Conflicts with employees of the same job level from } \\
\text { different departments motivate me the most to seek } \\
\text { transfer to other departments in the organization }\end{array}$ & 3.96 & 1.04 & 10.64 & 0.00 \\
\hline 13 & $\begin{array}{l}\text { Conflicts with employees in the same organizational } \\
\text { units motivate me the most to seek transfer to other } \\
\text { departments in the organization }\end{array}$ & 3.57 & 1.03 & 6.38 & 0.00 \\
\hline 14 & $\begin{array}{l}\text { Conflicts with owners motivate me the most to seek } \\
\text { transfer to other departments in the organization }\end{array}$ & 3.17 & 1.13 & 2.92 & 0.02 \\
\hline 15 & $\begin{array}{l}\text { Conflicts with customers motivate me the most to seek } \\
\text { transfer to other departments in the organization }\end{array}$ & 2.87 & 1.43 & -1.09 & 0.28 \\
\hline 16 & $\begin{array}{l}\text { Inner conflicts and own problems motivate me the } \\
\text { most to seek transfer to other departments in the } \\
\text { organization }\end{array}$ & 2.36 & 1.80 & -4.13 & 0.00 \\
\hline Total & & 3.19 & 1.23 & 1.71 & 0.09 \\
\hline
\end{tabular}


not statistically significant. Instead, it means that organizational conflicts do not affect employees and internal turnover of employees (conflicts between employees and top management, conflicts between employees and middle management, conflicts between employees and customers, and inner conflicts of employees.

- The mean value for all paragraphs was 3.19, and the statistical significance was less than 0.05. Generally, organizational conflicts affect employees and internal turnover. So, the hypothesis is proved to be true.

\subsection{Hypothesis 2}

There is a high impact of organizational conflicts on the external turnover in the hospitals, including conflicts between employees and top management, conflicts between employees and middle management, conflicts between employees and direct supervisors, conflicts between employees and other employees of the same level from different departments, conflicts between employees and other employees in the same organizational units, conflicts between employees and owners, conflicts between employees and customers, and inner conflicts of employees.

Table 6 shows that the mean value for paragraphs $17,19,21,23$, and 24 was more than 3.00. The statistical significance was less than 0.05 , which means that organizational conflicts affect employees and external turnover (conflicts between employees and top management, conflicts between employees and direct supervisors, conflicts between employees and other employees from the same department, conflicts between employees and customers, and inner conflicts of employees).

However, the mean value for paragraphs 18,20 , and 22 was less than 3.00 , which means that it is not statistically significant. Instead, it means that organizational conflicts do not affect employees and external turnover (conflicts between employees and middle management, conflicts between employees and other employees from different departments, and conflicts between employees and owners).

Nevertheless, the mean value for all paragraphs was 3.51, which is more than 3.00 , and the statistical significance was less than 0.05 . Generally, organizational conflicts affect employees and external turnover. So, the hypothesis is proved to be true.

\subsection{Hypothesis 3}

There are statistically significant differences in the impact of organizational conflicts of employees on employee turnover according to the following personal characteristics: sex, years of job experience, and job title (see Table 7).

Table 6. Means, standard deviations, and $T$ values for external turnover

\begin{tabular}{|c|c|c|c|c|c|}
\hline No. & Item & Mean values & $\begin{array}{l}\text { Standard } \\
\text { deviations }\end{array}$ & $T$-values & $\begin{array}{c}\text { Statistical } \\
\text { significance }\end{array}$ \\
\hline 17 & $\begin{array}{l}\text { Conflicts with top management motivate me the most } \\
\text { to leave work for another organization }\end{array}$ & 4.09 & 0.89 & 14.20 & 0.00 \\
\hline 18 & $\begin{array}{l}\text { Conflicts with middle management motivate me the } \\
\text { most to leave work for another organization }\end{array}$ & 2.99 & 1.41 & -0.12 & 0.90 \\
\hline 19 & $\begin{array}{l}\text { Conflicts with direct supervisors motivate me the most } \\
\text { to leave work for another organization }\end{array}$ & 4.10 & 0.94 & 13.50 & 0.00 \\
\hline 20 & $\begin{array}{l}\text { Conflicts with the other employees of the same job level } \\
\text { from different departments motivate me the most to } \\
\text { leave work for another organization }\end{array}$ & 2.45 & 1.81 & -3.53 & 0.00 \\
\hline 21 & $\begin{array}{l}\text { Conflicts with the other employees in the same } \\
\text { organizational units motivate me the most to leave work } \\
\text { for another organization }\end{array}$ & 3.29 & 1.05 & 0.00 & 0.00 \\
\hline 22 & $\begin{array}{l}\text { Conflicts with owners motivate me the most to leave } \\
\text { work for another organization }\end{array}$ & 2.47 & 1.79 & -3.42 & 0.00 \\
\hline 23 & $\begin{array}{l}\text { Conflicts with customers motivate me the most to leave } \\
\text { work for another organization }\end{array}$ & 4.02 & 0.94 & 12.62 & 0.00 \\
\hline 24 & $\begin{array}{l}\text { Inner conflicts and own problems motivate me the most } \\
\text { to leave work for another organization }\end{array}$ & 4.64 & 0.95 & 20.11 & 0.00 \\
\hline \multicolumn{2}{|r|}{ Total } & 3.51 & 1.07 & 5.18 & 0.00 \\
\hline
\end{tabular}


Table 7. The results of $T$ values, $F$ values, and the level of significance shown based on the demographic variables

\begin{tabular}{l|c|c|c}
\hline \multicolumn{1}{c|}{ Variable } & T value & F value & Level of significance \\
\hline Sex & 0.51 & $\ldots .60$ \\
Job title & 0.62 & $\ldots$ & 0.54 \\
Years of experience & $\ldots$ & 0.18 & 0.98 \\
\hline
\end{tabular}

There is statistical significance for the influence of organizational conflicts of employees on turnover based on personal variables (sex). Table 7 shows that the level of significance was more than 0.05 , which means that it is not statically significant. So, the hypothesis is rejected.

There is statistical significance for the influence of the organizational conflicts of employees on turnover based on the years of job experience. Table 7 shows that the level of significance was more than 0.05 , which means that it is not statically significant. So, the hypothesis is rejected.

There is statistical significance for the influence of the organizational conflicts of the employees on turnover based on the job title. According to Table 7 , the level of significance was more than 0.05 , which means that it is not statically significant. So, the hypothesis is rejected.

\section{CONCLUSION}

The study concluded that the highest levels of organizational conflicts in private hospitals in Jordan are inner or psychological conflicts of employees. They are followed by conflicts between employees and direct supervisors, conflicts between employees and customers, and conflicts between employees and top management. The study concluded that there are middle-level conflicts between employees and other employees of the same job level from different departments, and conflicts between employees and other employees from the same organizational units.

The study revealed low-level conflicts between employees and owners, as well as between employees and middle management. While the highest impact of organizational conflicts on the internal employee turnover in private hospitals was as follows: conflicts between employees and direct supervisors, conflicts between employees and other employees of the same job level from different departments, conflicts between employees and other employees in the same organizational units, conflicts between employees and owners. In addition, the highest impact of organizational conflicts on the external employee turnover in private hospitals was as follows: conflicts between employees and top management, conflicts between employees and direct supervisors, conflicts between employees and other employees in the same organizational units, conflicts between employees and customers, and inner conflicts of employees. Moreover, there were no statistically significant organizational conflict effects on turnover of employees based on demographic variables such as sex, years of job experience, and job title.

Following the results, private hospitals are recommended to provide an appropriate work environment for employees, develop the high level of well-being, and decrease the workload to create stability, which prevents work pressure and tensions. Regarding relations between employees and management units, mutual trust and respect must be developed and assured. In addition, the level of social relations among employees needs to be enhanced. Moreover, organizational culture needs to be developed, which guarantees employees justice when it comes to various privileges, allocation of tasks and duties without discrimination. In addition, top management in private hospitals must protect their employees from direct intervention of owners into work affairs. Employees should be in direct contact with the head of their unit, and top management has to follow up on the organizational conflicts and find all means to solve problems before they turn into real catastrophes. 


\section{AUTHOR CONTRIBUTIONS}

Conceptualization: Akif Al-Khasawneh, Bassam Abu Khadar.

Data curation: Akif Al-Khasawneh, Bassam Abu Khadar.

Formal analysis: Akif Al-Khasawneh, Bassam Abu Khadar.

Funding acquisition: Akif Al-Khasawneh, Bassam Abu Khadar.

Investigation: Akif Al-Khasawneh, Bassam Abu Khadar.

Methodology: Akif Al-Khasawneh, Bassam Abu Khadar.

Project administration: Akif Al-Khasawneh, Bassam Abu Khadar.

Resources: Akif Al-Khasawneh, Bassam Abu Khadar.

Software: Akif Al-Khasawneh, Bassam Abu Khadar.

Supervision: Akif Al-Khasawneh, Bassam Abu Khadar.

Validation: Akif Al-Khasawneh, Bassam Abu Khadar.

Visualization: Akif Al-Khasawneh, Bassam Abu Khadar.

Writing - original draft: Akif Al-Khasawneh, Bassam Abu Khadar.

Writing - review \& editing: Akif Al-Khasawneh, Bassam Abu Khadar.

\section{ACKNOWLEDGMENTS}

We would like to thank Al-Balqa Applied University in the Kingdom of Jordan and the Institute of Public Administration in the Kingdom of Saudi Arabia for their kind support and for giving us access to the research facilities.

\section{REFERENCES}

1. Alfreihat, K., Al-Luzi, M., \& AlShihabi, A. (2009). Organizational Behavior: Contemporary Concepts. Amman: Ethraa for Publishing and Distribution.

2. Al-Khasawneh, A. L. (2013). Effect of Organizational Climate on Job Turnover of Employees at Tourism Hotels in Petra Region of Jordan. American Journal of Social and Management Sciences, 4(2), 54-62. http://doi:10.5251/ ajsms.2013.4.2.54.62

3. Al-Khasawneh, A. L., Malkawi, N. M., \& Algarni, A. (2018). Sources of recruitment at foreign commercial banks in Jordan and their impact on the job performance proficiency. Banks and Bank Systems, 3(2), 12-26. http://dx.doi.org/10.21511/ bbs.13(2).2018.02

4. Al-Shourah, A. (2015). The impact of conflict management or organizational effectiveness (A case study: Ministry of higher education of Jordan). European Journal of Business Management, 7(36), 75-85. Retrieved from https://www.semanticscholar.org/ paper/The-Impact-of-ConflictManagement-on-Organizational-A. S/3e0eefc5cea4e20c2a2e358d3595a cb9eca86da8

5. Buchanan, D., \& Huczynski, A. (2004). Organizational behavior: An introductory text $\left(5^{\text {th }} \mathrm{ed}\right.$.). England: Pearson Education Limited.

6. Eunice, M., Jacqueline, K., Buyeke, E., Wafula, M., \& Musyoki, J. (2015). Effects of interpersonal conflict on organizational performance in selected hotels in Kesiitown, Kenya. African Journal of Hospitality, Tourism and Leisure 4(1), 1-5. Retrieved from https:// www.academia.edu/13607463/EFFECTS_OF_INTERPERSONAL_ CONFLICTS_ON_ORGANISATIONAL_PERFORMANCE

7. Garcia, M. (2013). Organizational conflict and organizational performance. Asian Educational Research Association, 11(1), 41-45. Retrieved from http://citeseerx.ist. psu.edu/viewdoc/download?doi= 10.1.1.1084.1619\&rep=rep1\&typ $\mathrm{e}=\mathrm{pdf}$
8. Greenberg, J., \& Baron, R. A (2003). Behavior in organizational understanding and managing the human side of work ( $8^{\text {th }} \mathrm{ed}$.). New Jersey: Upper Saddle River, Pearson Education.

9. Hellriegel, D., Slocum, Jr., John, W., \& Woodman, R. W. (2001). Organizational Behavior ( $9^{\text {th }}$ ed.). Cincinnati, Ohio: South-Western College Publishing.

10. Hotep, O. M., Asokere, A. S., Abdul-Aziz, I. A., \& Ajemunigbohun, S. S. (2010). An empirical study of the effect of conflict on organizational performance in Nigeria. Business and Economics Journal, 15, 1-9. Retrieved from https:// www.hilarispublisher.com/ open-access/empirical-studyof-the-effect-of-conflict-onorganizational-performance-innigeria-2151-6219-1-015.pdf

11. Igbokwe, A. (2014). Is organizational conflict healthy for the growth of an organization? Merit Research Journal of Art, Social Science and Humanities, 
2(3), 25-30. Retrieved from https://meritresearchjournals. org/assh/Content/2014/April/ Igbokwe.pdf

12. Jawad, S. N. (2000). Organizational Behavior. Amman: Dar Al-Hamed Publishing.

13. Keith, D. (1998). Human Behavior: Organizational Behaviors (6 ${ }^{\text {th }}$ ed.). New Delhi: Jaico Publishing House.

14. Kondalkar, V. G. (2007) Organizational Behavior. New Delhi: New Age International (P) Limited, Publishers.

15. Longe, O. (2015). Impact of workplace conflict management on organizational performance: A case of Nigerian manufacturing. Journal of Management and Strategy, 6(2), 83-92. http://doi. org/10.5430ljms-v6n2p83

16. Longenecker, J., \& Pringle, C. (1984). Management ( $6^{\text {th }}$ ed.). Columbus, Ohio: Charles E. Merrill Company.

17. Malkawi, N. M. (2017). Enhancing Entrepreneurship through E-Commerce Adoption-Applied Study at Small Companies. International Journal of Research in Management, Economics and Commerce, 7(1). Retrieved from http://www.indusedu.org/pdfs/ IJRMEC/IJRMEC_1049_69037. pdf

18. Malkawi, N. M. (2018). How to Improve Decision-Making Process through Decision Support Systems \& Business Intelligence: Evidence from Jordan University Hospital. Journal of Economics \& Management Perspectives, 12(2). Retrieved from https://www. proquest.com/openview/fb4a954 29bd807d9c75e502f5910d79b/1? pq-origsite $=$ gscholar $\& \mathrm{cbl}=51667$

19. Malkawi, N., \& Al-Omari, K. (2020). The Role of Organizational Justice in Managing Organizational Conflict - Case Study at Jordanian Marseilles company for Real Estate Investments/
Irbid City Center- Irbid- Jordan. International Journal of Research in Engineering, IT and Social Sciences, 10(7), 43-56. Retrieved from https://www.academia. edu/43678899/

20. Medina, E. (2012). Job satisfaction and employee turnover intention: what does organizational culture have to do with it? (Master's thesis). Columbia University, USA. Retrieved from https://static1.1.sqspcdn. com/static/f/1528810/23319899/1376576545493/ Medina+Elizabeth.pdf

21. Moorhead, G., \& Griffin, R. (1995). Organizational Behavior: Managing People and Organizations ( $4^{\text {th }}$ ed.). Boston: Houghton Mifflin Company.

22. Omisore, B., \& Abiodun, A. (2014). Organizational conflict: causes, effects and remedies. International Journal of Academic Research in Economics and Management Sciences, 3(6), 118-137. https://doi.org/10.6007/ IJAREMS/v3-i6/1351

23. Omyan, M. (2005). Organizational Behavior in Business Organizations ( $3^{\text {rd }}$ ed.). Amman: Dar Wael for Publishing and Distribution.

24. Saeed, I., Waseem, M., \& Sikander S. (2014). The relationship of turnover intention with job satisfaction, job performance, Leadermember exchange, Emotional intelligence and organizational commitment. International Journal of Learning \& Development, 4(2), 242-256. http://doi.org/10.5296/ ijld. v4i2.6100

25. Said, N. S., Mori, C. S., Bidrul, A. S., Ali, O. S., Yusof, M. H., \& Mat, A. K. (2016). The relationship between workplace conflict and job performance: A study of staff in Terengganu higher learning institution. Journal of Applied Environmental and Biological Sciences, 6(35), 27-32. Retrieved from https:// www.semanticscholar.org/paper/ The-Relationship-between-
Workplace-Conflict-and-JobSaid-Mori/39de7ca5d6a0ef69d25 9e13aadff9a50395dbed4

26. Shin, J. H. (2009). Developing constructive and proactive conflict management strategies in healthcare. Journal of Communication in Healthcare, 2(1), 78-94. https://doi. org/10.1179/cih.2009.2.1.78

27. Wang, Y., Li, Z., Wang, Y., \& Gao, F. (2017). Psychological Contract and Turnover Intention: The Mediating Role of Organizational Commitment. Journal of Human Resource and Sustainability Studies, 5, 21-35. http://doi.org/10.4236/ jhrss.2017.51003 